Mеталлофиз. новейшие технол. / Metallofiz. Noveishie Tekhnol. (C) 2018 ИМФ (Институт металлофизики 2018, т. 40, № 5, сс. 585-592 / DOI: $10.15407 /$ mfint.40.05.0585 им. Г. В. Курдюмова НАН Украины) Оттиски доступны непосредственно от издателя

Фотокопирование разрешено только

Напечатано в Украине.

в соответствии с лицензией

PACS numbers: 32.30.Rj, 32.80.Zb, 34.80.Dp, 78.70.En, 79.20.Ap, 79.20.Kz

\title{
The $K_{\alpha} L^{1}, K_{\alpha} L^{2}$, and $K_{\alpha} L^{3}$ X-Ray Emission of Aluminium under
} Electron Impact

\author{
M. A. M. Al-Omari and M. O. Borovyi \\ Taras Shevchenko National University of Kyiv, \\ Physics Faculty, \\ 60 Volodymyrska Str., \\ UA-01033 Kyiv, Ukraine
}

The relative intensities, $\gamma=I\left(K_{\alpha} L^{1}\right) / I\left(K_{\alpha_{1,2}}\right), \eta=I\left(K_{\alpha} L^{2}\right) / I\left(K_{\alpha} L^{1}\right)$ and $\chi=$ $=I\left(K_{\alpha} L^{3}\right) / I\left(K_{\alpha} L^{1}\right)$, of x-ray emission $K_{\alpha_{1,2}}, K_{\alpha} L^{1}, K_{\alpha} L^{2}$, and $K_{\alpha} L^{3}$ lines' groups of aluminium are experimentally studied under the excitation by electron impact in the range of accelerating voltages $U=4.5-100 \mathrm{kV}$. The model of $K_{\alpha}$ $\mathrm{x}$-ray emission has been proposed and takes into account the main channels of multiply ionized $K L_{2,3}^{n}$ states' decay. As found, the probabilities of creation of $K L_{2,3}$ configuration $\left(P_{1}\right), K L_{2,3}^{2}$ configuration $\left(P_{2}\right)$ and $K L_{2,3}^{3}$ configuration $\left(P_{3}\right)$ monotonically decrease when bombarding-electron energy $E>20 \mathrm{keV}$. The observed decrease of the $P_{1}, P_{2}$ and $P_{3}$ values can be explained by decreasing of the average energy transferred to the atom in electron-atom collision. The $P_{2}$ and $P_{3}$ probabilities significantly exceed (by 1.6 to 2.5 times) their values predicted within the shake-off approximation of simultaneous independent ejecting of two and three $2 p$ electrons that indicates a significant role of the $2 p-2 p$ electron correlations in $K L_{2,3}^{n}$ ionization processes. As shown, the $P_{21}=P_{2} / P_{1}$ and $P_{31}=P_{3} / P_{1}$ ratios are practically constant in the whole range of accelerating voltages and are the parameters characterizing the values of $2 p-2 p$ electron correlations.

Key words: $K_{\alpha} \mathrm{x}$-ray emission, multiply ionized $K L_{2,3}^{n}$ states, $2 p-2 p$ electron correlations.

Відносні інтенсивності $\gamma=I\left(K_{\alpha} L^{1}\right) / I\left(K_{\alpha_{1,2}}\right), \quad \eta=I\left(K_{\alpha} L^{2}\right) / I\left(K_{\alpha} L^{1}\right) \quad$ та $\chi=$ $=I\left(K_{\alpha} L^{3}\right) / I\left(K_{\alpha} L^{1}\right)$ груп рентґенівських емісійних ліній $K_{\alpha_{1.2}}, K_{\alpha} L^{1}, K_{\alpha} L^{2}$ та

Corresponding author: Al-Omari Mohammad Abdulla Mohammad

E-mail: d.alomari13@gmail.com

Citation: M. A. M. Al-Omari and M. O. Borovyi, The $K_{\alpha} L^{1}, K_{\alpha} L^{2}$, and $K_{\alpha} L^{3}$ X-Ray Emission of Aluminium under Electron Impact, Metallofiz. Noveishie Tekhnol., 40, No. 5: 585-592 (2018), DOI: 10.15407/mfint.40.05.0585. 
$K_{\alpha} L^{3}$ алюмінію експериментально досліджено при електронному бомбуванні у діяпазоні прискорювальних напруг $U=4,5-100$ кВ. Запропоновано модель рентґенівської $K_{\alpha}$-емісії, яка враховує основні канали розпаду кратно йонізованих $K L_{2,3}^{n}$-станів. Встановлено, що ймовірності створення станів $K L_{2,3}$-конфігурації $\left(P_{1}\right), K L_{2,3}^{2}$-конфігурації $\left(P_{2}\right)$ та $K L_{2,3}^{3}$-конфігурації $\left(P_{3}\right)$ монотонно зменшуються в області енергій бомбівних електронів $E>20$ кеВ. Зменшення величин $P_{1}, P_{2}$ та $P_{3}$, яке спостерігається експериментально, може бути зумовленим зменшенням середньої енергії, що передається атому при електрон-атомному зіткненні. Ймовірності $P_{2}$ та $P_{3}$ значно перевищують (від 1,6 до 2,5 разів) відповідні значення, визначені у наближенні миттєвого незалежного вильоту двох і трьох $2 p$-електронів, що свідчить про істотну роль $2 p-2 p$-електронних кореляцій у процесах $K L_{2,3}^{n}$-йонізації. Показано, що відношення $P_{21}=P_{2} / P_{1}$ та $P_{31}=P_{3} / P_{1}$ зберігаються практично сталими в усьому діяпазоні прискорювальних напруг i є параметрами, що характеризують величину $2 p-2 p$-електронних кореляцій.

Ключові слова: $K_{\alpha}$ рентгенівська емісія, кратно йонізовані $K L_{2,3}^{n}$-стани, $2 p-2 p$-електронні кореляції.

Относительные интенсивности $\gamma=I\left(K_{\alpha} L^{1}\right) / I\left(K_{\alpha_{1,2}}\right), \eta=I\left(K_{\alpha} L^{2}\right) / I\left(K_{\alpha} L^{1}\right)$ и $\chi=$ $=I\left(K_{\alpha} L^{3}\right) / I\left(K_{\alpha} L^{1}\right)$ групп рентгеновских эмиссионных линий $K_{\alpha 1,2}, K_{\alpha} L^{1}$, $K_{\alpha} L^{2}$ и $K_{\alpha} L^{3}$ алюминия экспериментально исследованы при электронной бомбардировке в диапазоне ускоряющих напряжений $U=4,5-100 \kappa \mathrm{B}$. Предложена модель рентгеновской $K_{\alpha}$-эмиссии, которая учитывает основные каналы распада кратно ионизированных $K L_{2,3}^{n}$-состояний. Установлено, что вероятности создания состояний $K L_{2,3}$-конфигурации $\left(P_{1}\right)$, $K L_{2,3}^{2}$-конфигурации $\left(P_{2}\right)$ и $K L_{2,3}^{3}$-конфигурации $\left(P_{3}\right)$ монотонно уменьшаются в области энергий бомбардирующих электронов $E>20$ кэВ. Уменьшение величин $P_{1}, P_{2}$ и $P_{3}$, наблюдаемое экспериментально, может быть обусловлено уменьшением средней энергии, которая передаётся атому при электрон-атомном столкновении. Вероятности $P_{2}$ и $P_{3}$ значительно превышают (от 1,6 до 2,5 раза) соответствующие значения, определённые в приближении мгновенного независимого вылета двух и трёх $2 p$-электронов, что свидетельствует о существенной роли $2 p-2 p$ электронных корреляций в процессах $K L_{2,3}^{n}$-ионизации. Показано, что отношения $P_{21}=P_{2} / P_{1}$ и $P_{31}=P_{3} / P_{1}$ сохраняются практически постоянными во всем диапазоне ускоряющих напряжений и являются параметрами, которые характеризуют величину $2 p-2 p$-электронных корреляций.

Ключевые слова: $K_{\alpha}$-рентгеновская эмиссия, кратно ионизированные $K L_{2,3}^{n}$-состояния, $2 p-2 p$-электронные корреляции.

(Received February 5, 2018)

\section{INTRODUCTION}

The ionization of the $K$ shell of an atom by photon or electron may be accompanied by autoionization with the formation of one or more $(n)$ 
additional vacancies in the $L_{2,3}$ subshells [1-3]. The same multiply ionized end states also arise upon ion bombardment; however, the direct $K L_{2,3}^{n}$ ionization mechanism is crucial in that case [4]. The nature of the autoionization process, the main one under photoionization or electrons' impact, is associated with the 'shaking off' of the $2 p$ electrons as a result of the fast self-consistent field change upon the occurrence of a $K$-vacancy ('shake-off'-SO). It is important that the probability of another additional $L$-vacancy formation by the SO mechanism can be calculated with a good accuracy within the sudden approximation [57]. However, even in the simplest case, it was experimentally found that some features of the double $K L_{2,3}$ ionization cannot be explained solely by the SO process. For instance, the cross-section ratio $\sigma\left({ }^{3} P\right) / \sigma\left({ }^{1} P\right)$ of the ${ }^{3} P$ and ${ }^{1} P$ terms for $\mathrm{Si}$ and $\mathrm{Cr}$ atoms reveals a different near-threshold behaviour during photoabsorption and electron impact that cannot be explained without accounting for the multielectron effects in the atomic core-slow ejected $1 s, 2 p$ electrons' system $[8,9]$. Presumably, the role of multielectron effects at the formation of one, two, and three additional $L_{2,3}$ vacancies (with configurations of $K L_{2,3}$, $K L_{2,3}^{2}$, and $K L_{2,3}^{3}$, respectively) will increase with the multiplicity of the additional $L_{2,3}$ ionization as the electron-electron correlations are the strongest for autoionization electrons from one subshell [10]. Thus, a comparative experimental study of the probabilities of additional $L_{2,3}$ ionization $\left(P_{1}\right), L_{2,3}^{2}$ ionization $\left(P_{2}\right)$ and $L_{2,3}^{3}$ ionization $\left(P_{3}\right)$ at different energies of bombarding electrons allow quantifying the magnitude of the $2 p-2 p$ correlation interaction after ionization on the energy of the incident electron (perturbation rate) as well as on the multiplicity of the $K L_{2,3}^{n}$ ionization. To the best of our knowledge, theoretical calculations of the $K L_{2,3}^{n}$ ionization probabilities taking into account the post-collision interaction between the slow two and three $2 p$ electrons as well as with the atomic core are not available in the literature. Therefore, such an experiment is of great interest.

Experimental information about the $P_{1}, P_{2}$, and $P_{3}$ probabilities can be obtained from the relative intensities of the x-ray emission $K_{\alpha} L^{1}$, $K_{\alpha} L^{2}$, and $K_{\alpha} L^{3}$ satellite groups, for which the initial $K L_{2,3}, K L_{2,3}^{2}$, and $K L_{2,3}^{3}$ configurations are as follow: the $K_{\alpha} L^{1}$ group corresponds to the $K L_{2,3}-L_{2,3}^{2}$ radiative transitions, the $K_{\alpha} L^{2}$ group-the $K L_{2,3}^{2}-L_{2,3}^{2}$ radiative transitions, and the $K_{\alpha} L^{3}$ group - the $K L_{2,3}^{3}-L_{2,3}^{4}$ radiative transitions $[11,12]$. In the present paper, the relative intensities of $\mathrm{x}$-ray emission $\mathrm{Al} K_{\alpha}$ satellite groups $K_{\alpha} L^{1}, K_{\alpha} L^{2}$, and $K_{\alpha} L^{3}$ are experimentally studied under electron impact in a wide range of incident electron energies.

\section{EXPERIMENTAL METHOD}

Aluminium was used as a sample for several reasons. It is a metal, in 
which the interaction of an outgoing $2 p$ electron with an atomic core is effectively shielded by conduction electrons. The $\mathrm{Al} K_{\alpha}$ spectrum can be well resolved by quartz crystal-analysers into individual satellite groups corresponding to various ionization multiplicities as well as into individual components within the group. Additionally, relatively weak group lines $K_{\alpha} L^{2}$ and $K_{\alpha} L^{3}$ of $\mathrm{Al}$ are still reasonably detectable using step-by-step scanning with longer accumulation times.

The x-ray emission $\mathrm{Al} K_{\alpha}$ lines were excited by an electron beam in the range of incident electron energies $E=4.5-100 \mathrm{kV}$. The $K_{\alpha}$ spectrum were registered in the first order of reflection from the $(10 \overline{1} 1)$ planes of the quartz monocrystal bent according to Johann in the stepby-step regime (with the step sizes of $0.1-0.4 \mathrm{eV}$ ); the accumulation time in a point is of 1-50 $\mathrm{s}$. The method of spectrograms processing is given in Refs. $[8,13,14]$. The corrections were done taking into account the angular dependence of the reflection coefficient of the quartz-analyser as well as the spectrometer dispersion upon the transfer from the angle scale to the energy scale. A typical $\mathrm{Al} K_{\alpha}$ spectrum is shown in Fig. $1 \quad(E=25 \mathrm{keV})$. The relative intensities $\gamma=$ $=I\left(K_{\alpha} L^{1}\right) / I\left(K_{\alpha_{1,2}}\right), \eta=I\left(K_{\alpha} L^{2}\right) / I\left(K_{\alpha} L^{1}\right)$ along with $\chi=I\left(K_{\alpha} L^{3}\right) / I\left(K_{\alpha} L^{1}\right)$ were measured as the ratio of the areas under the experimental contours of the $K_{\alpha_{1,2}}$ lines and $K_{\alpha} L^{1}, K_{\alpha} L^{2}, K_{\alpha} L^{3}$ satellites, which were singled out from the slope of $K_{\alpha_{1,2}}$. The relative error in determining the $\eta$ and $\chi$ values did not exceed $5-8 \%$.

\section{RESULTS AND DISCUSSION}

It is important to note that not only the radiative transitions associated with the decay of $K L_{2,3}^{2}$ configurations contribute to the $K_{\alpha} L^{2}$ satellite intensity. The $K L_{1} L_{2.3}$ and $K L_{1}^{2}$ configurations need to be considered as well. Furthermore, for some of the atoms, the states of the $K L_{2,3}^{2}$ configuration are created bv the $K L_{1} L_{2,3}-K L_{2,3}^{2} M$ and $K L_{1}^{2,3}-K L_{2,3}^{2} M^{2}$ Coster-Kronig transitions. It applies to the $K L_{2,3}^{3}$ configuration as well. Therefore, the contributions of these processes to the intensity of the $K_{\alpha} L^{2}$ and $K_{\alpha} L^{3}$ Al satellites were evaluated using values of the total widths of the $K$ and $L$ levels [15], the Auger and Coster-Kronig yields [16], and the $2 p$ electron SO probability in occurrence of $K$ vacancy [6,7]. It has established that the maximum contribution of such processes to the corresponding intensity does not exceed $10-12 \%$ in case of Al. Therefore, the experimentally determined intensities $I\left(K_{\alpha} L^{2}\right)$ and $I\left(K_{\alpha} L^{3}\right)$ were reduced by $11 \%$.Thus, the creation of satellites due to the Auger and Coster-Kronig processes are not considered.

As given above, the relative intensities $I\left(K_{\alpha_{1,2}}\right), I\left(K_{\alpha} L^{1}\right), I\left(K_{\alpha} L^{2}\right)$, and $I\left(K_{\alpha} L^{3}\right)$ are determined by the equations (to within the constant common factor): 


$$
\begin{gathered}
I\left(K_{\alpha_{1,2}}\right)=\sigma_{K}\left(1-P_{1}\right) \frac{\Gamma_{\alpha}^{R}}{\Gamma_{K}}\left(P_{1}>>P_{2}, P_{3}\right), \\
I\left(K_{\alpha} L^{1}\right)=\sigma_{K} P_{1} \frac{(5 / 6) \Gamma_{\alpha}^{R}}{a_{1} \Gamma_{K}^{A}+k_{1} \Gamma_{K}^{R}+\Gamma_{L}}, \\
I\left(K_{\alpha} L^{2}\right)=\sigma_{K} P_{2} \frac{(2 / 3) \Gamma_{\alpha}^{R}}{a_{2} \Gamma_{K}^{A}+k_{2} \Gamma_{K}^{R}+2 \Gamma_{L}} \\
I\left(K_{\alpha} L^{3}\right)=\sigma_{K} P_{3} \frac{(1 / 2) \Gamma_{\alpha}^{R}}{a_{3} \Gamma_{K}^{A}+k_{3} \Gamma_{K}^{R}+3 \Gamma_{L}}
\end{gathered}
$$

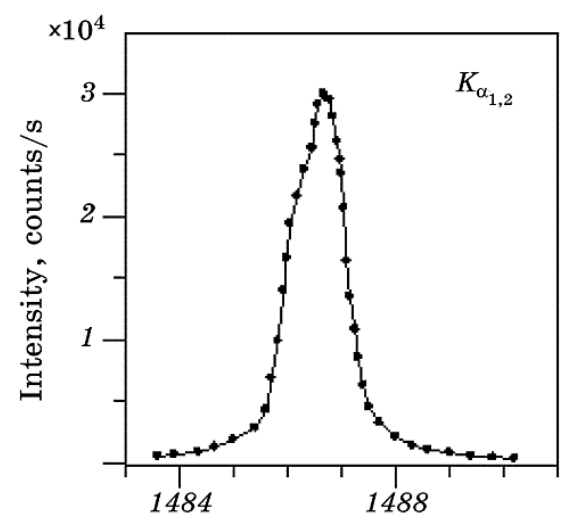

Photon energy, eV

$a$

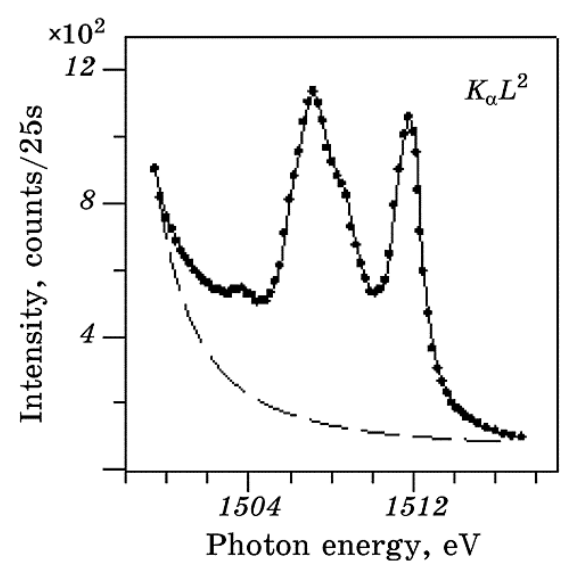

$c$

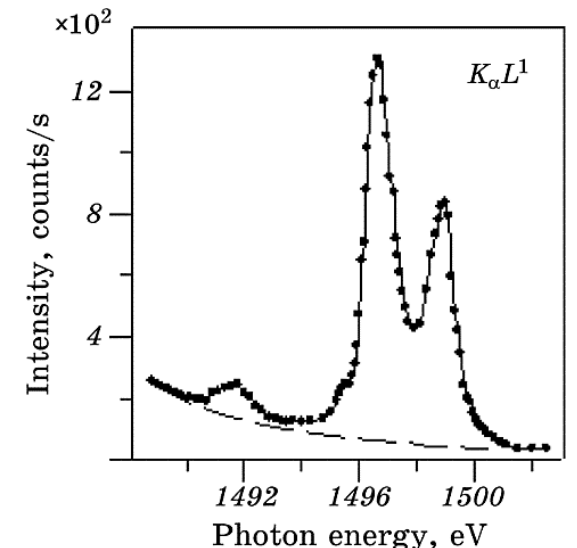

$b$

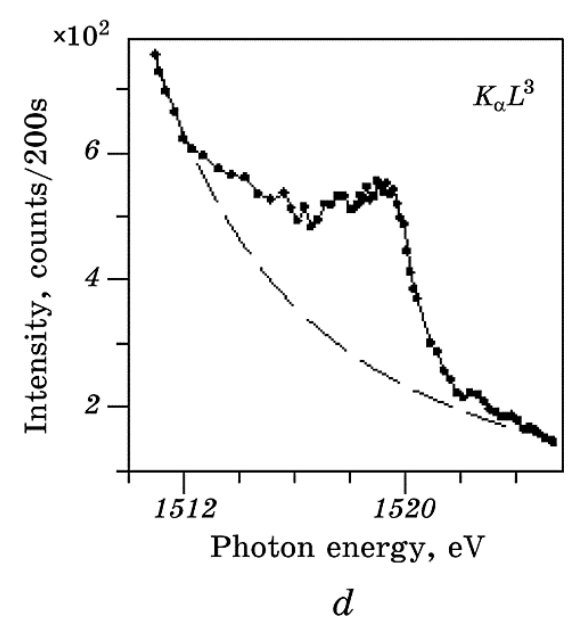

Fig. 1. X-ray $K_{\alpha}$ spectrum of Al: $a-K_{\alpha_{1}}, b-K_{\alpha} L^{1} ; c-K_{\alpha} L^{2} ; d-K_{\alpha} L^{3}$. 
Therefore,

$$
\begin{gathered}
P_{1}=\frac{\gamma}{\gamma+G}, P_{2}=\eta P_{1} N, P_{3}=\chi P_{1} M, \\
G=\frac{5}{6} \frac{\Gamma_{K}}{a_{1} \Gamma_{K}^{A}+k_{1} \Gamma_{K}^{R}+\Gamma_{L}}, N=\frac{5}{4} \frac{a_{2} \Gamma_{K}^{A}+k_{2} \Gamma_{K}^{R}+2 \Gamma_{L}}{a_{1} \Gamma_{K}^{A}+k_{1} \Gamma_{K}^{R}+\Gamma_{L}}, \\
M=\frac{5}{3} \frac{a_{3} \Gamma_{K}^{A}+k_{3} \Gamma_{K}^{R}+3 \Gamma_{L}}{a_{1} \Gamma_{K}^{A}+k_{1} \Gamma_{K}^{R}+\Gamma_{L}} .
\end{gathered}
$$

In formulas (1)-(5), $\sigma_{K}$-the $K$ shell ionization cross-section, $\Gamma_{K}$ and $\Gamma_{L}$ - the width of $K$ and $L_{2,3}$ levels, $\Gamma_{\alpha}^{R}$ - the width of the $K-L_{2,3}$ radiative transition, $\Gamma_{K}^{A}$, $\Gamma_{K}^{R}$ - the Auger and radiative components of the $K$ level width. The coefficients $5 / 6,2 / 3$ and $1 / 2$ take into account the reducing of the number of $2 p$ electrons with the increasing multiplicity of ionization; $a_{1}, a_{2}, a_{3}$-the decreasing of $\Gamma_{K}^{A}, k_{1}=5 / 6 ; k_{2}=2 / 3, k_{3}=$ $=1 / 2$ - the $\Gamma_{K}^{R}$ decreasing at the formation of the one, two and three additional $L_{2,3}$ vacancies, respectively. Taking into account the rates of $K L_{i} L_{j}$ and $K L_{i} M_{j}$ Auger transitions [17], the following parameters were obtained: $a_{1}=0.82, a_{2}=0.64, a_{3}=0.35$. We used the values as follow: $\Gamma_{K}=0.420 \mathrm{eV}, \Gamma_{L}=0.004 \mathrm{eV}$ [15], the fluorescence yield $\omega_{K}=0.039$ [16], resulting in $G=1.12, N=0.47, M=0.32$.

Thus, the values of the $P_{1}, P_{2}$, and $P_{3}$ probabilities were experimentally determined at various incident electron energies based on the relative intensities $\gamma, \eta$, and $\chi$. They are listed in Table 1 . The experimental probabilities $P_{1}, P_{2}$, and $P_{3}$ demonstrated monotonically decrease with increasing incident electron energy above $20 \mathrm{keV}$. The decreasing of $P_{1}, P_{2}$, and $P_{3}$ with the incident electron energy may be re-

TABLE 1. Parameters of the $K_{\alpha} L^{1}, K_{\alpha} L^{2}$, and $K_{\alpha} L^{3}$ lines and of the $K L_{2,3}^{n}$ ionization processes.

\begin{tabular}{c|ccc|c|c|c|c|c}
\hline \multirow{2}{*}{$\begin{array}{c}\text { Acceleration } \\
\text { voltage, } \mathrm{kV}\end{array}$} & \multicolumn{2}{|c|}{ Relative intensities } & $P_{1}, 10^{-2}$ & $P_{2}, 10^{-3}$ & $P_{3}, 10^{-5}$ & $P_{2,1}, 10^{-2}$ & $P_{3,1}, 10^{-4}$ \\
\hline 4.5 & 10.4 & 8.3 & 2.8 & 8.5 & 3.3 & 7.6 & 3.9 & 8.9 \\
7 & 9.9 & 8.5 & 3.0 & 8.1 & 3.1 & 7.8 & 4.0 & 9.6 \\
11 & 9.8 & 8.1 & 3.1 & 8.0 & 3.1 & 7.7 & 3.8 & 9.5 \\
17 & 9.5 & 8.2 & 3.1 & 7.8 & 2.9 & 7.7 & 3.9 & 9.9 \\
25 & 8.8 & 7.9 & 3.0 & 7.3 & 2.7 & 6.9 & 3.7 & 9.5 \\
50 & 8.1 & 8.2 & 2.9 & 6.7 & 2.5 & 6.1 & 3.9 & 9.1 \\
75 & 7.0 & 8.3 & 3.1 & 5.9 & 2.2 & 5.6 & 3.9 & 9.5 \\
100 & 6.5 & 8.1 & 3.0 & 5.5 & 2.1 & 5.4 & 3.8 & 9.8 \\
\hline
\end{tabular}


lated to the decreased average energy transferred to the atom in the electron-atom collision. Thus, the reduction of the transferred energy should be accompanied by decreasing of the velocity of the ejected $1 s$ electron and, in turn, the lowering of the SO processes probabilities.

The experimental values for $P_{2}$ and $P_{3}$ now will be compared with those calculated in the SO approximation $\left(P_{2}^{(\mathrm{SO})}\right.$ and $\left.P_{3}^{(\mathrm{SO})}\right)$ using the $P_{1}^{(\mathrm{SO})}$ values [6, 7]. The probability of a simultaneous independent ejection of two arbitrary $2 p$ electrons in the occurrence of the $K$ vacancy is equal to $P_{2}^{(\mathrm{SO})}=(5 / 12)\left(P_{1}^{(\mathrm{SO})}\right)^{2}$ (the probability of ejecting one certain $2 p$ electron being $\left.P_{1}^{(\mathrm{SO})} / 6\right)$, for the pair of certain $2 p$ electrons, $(1 / 36)\left(P_{1}^{(\mathrm{SO})}\right)^{2}$, the number of possible pairs is $6 ! /(2 ! 4 !)=15$. Similarly, in the case of independent simultaneous ejection of three arbitrary $2 p$ electrons, the probability is $P_{3}^{(\mathrm{SO})}=(5 / 54)\left(P_{1}^{(\mathrm{SO})}\right)^{3}$. For Al atoms, $P_{1}^{(\mathrm{SO})}=$ $=6.9 \cdot 10^{-2}[6,7]$, then the corresponding probabilities are $P_{2}^{(\mathrm{So})}=$ $=2.0 \cdot 10^{-3}$ and $P_{3}^{(\mathrm{SO})}=3 \cdot 1 \cdot 10^{-5}$. The comparison of the experimental data and the SO estimation shows that in the range of the most effective SO process $(E=5-15 \mathrm{keV})$ the experimental values of the probabilities $P_{2}$ and $P_{3}$ significantly exceed ones predicted within the approximation of independent 'shaking off', the discrepancy being proportional to the multiplicity of the additional $L_{2,3}$ ionization $\left(P_{2} / P_{2}^{(\mathrm{SO})}=1.6 ; P_{3} / P_{3}^{(\mathrm{SO})}=\right.$ =2.5). Therefore, the $K L_{2,3}^{2}$ and $K L_{2,3}^{3}$ ionization processes are essentially multielectron, and $2 p-2 p$ electron correlations should be included in the theoretical model of the multiple ionization.

Other parameters of the $K L_{2,3}^{n}$ ionization processes are the ratios $R_{2,1}=P_{2} / P_{1}$ and $R_{3,1}=P_{3} / P_{1}$, which determine the relative fractions of atoms with two and three additional $L_{2,3}$ vacancies. Importantly, the values of $R_{2,1}$ and $R_{3,1}$ are constant within the experimental error in the whole range of incident-electrons' energies. It means that $R_{2,1}$ and $R_{3,1}$ do not depend on the perturbation rate and characterize the values of $2 p-2 p$ electron correlations.

\section{CONCLUSIONS}

The relative intensities $\gamma, \eta$, and $\chi$ of $\mathrm{Al}$ x-ray emission $K_{\alpha} L^{1}, K_{\alpha} L^{2}$, and $K_{\alpha} L^{3}$ satellites under electron bombardment have been experimentally investigated in the energy range $E=4.5-100 \mathrm{keV}$. The x-ray emission model has been proposed that allows taking into account the main channels of creation and decay the states of $K L_{2,3}, K L_{2,3}^{2}$, and $K L_{2,3}^{3}$ configurations under electron impact. The formation probabilities of one, two and three additional $L_{2,3}$ vacancies $P_{1}, P_{2}$, and $P_{3}$ as result of $K$ ionization are determined. As established, the values of $P_{1}, P_{2}$, and $P_{3}$ monotonically decrease in the range $E>20 \mathrm{keV}$ that can be explained by decreasing of the average energy transferred to the atom in the electron-atom collision. The probabilities $P_{2}$ and $P_{3}$ are significantly exceed (by 1.6 to 2.5 times) the predicted in approximation of simultane- 
ous independent ejecting of two and three $2 p$ electrons that indicates a significant role of $2 p-2 p$ electron correlations in $K L_{2,3}^{n}$ ionization processes.

\section{REFERENCES}

1. V. P. Sachenko and V. F. Demekhin, $Z h E T F, 3$, No. 49: 765 (1965) (in Russian).

2. M. Kavčič, M. Budnar, and J. L. Campbell, Nucl. Instrum. Meth. B, 196, Nos. 1-2: 16 (2002).

3. V. Horvat, R. L. Watson, and Yong Peng, Phys. Rev. A, 74, No. 2: 022718 (2006).

4. J. Hoszovska, J.-Cl. Dousse, J. Kern, and Ch. Rheme, Nucl. Instrum. Meth.A, 376: 129 (1996).

5. T. Mukoyama and K. Taniguchi, Phys. Rev. A, 36, No. 2: 693 (1987).

6. A. G. Kochur and V. A. Popov, J. Phys. B, 35: 395 (2002).

7. A. G. Kochur, A. I. Dudenko, and D. Petrini, Optics and Spectroscopy, 100, No. 5: 645 (2006).

8. N. A. Borovoy, V.V. Ivanov, and V. I. Shiyanovskii, Optics and Spectroscopy, 86, No. 1: 11 (1999).

9. N. A. Borovoy, V. V. Ivanov, V. F. Surzhko, and V. I. Shiyanovskii, Ukr. Journ. Phys., 46, No. 1: 70 (2001).

10. M. Y. Amusia, Protsessy $v$ Mnogoelectronnykh Atomakh [Processes in Multielectron Atoms] (St. Petersburg: Nauka: 2006) (in Russian).

11. E. Mikkola and O. Keski-Rahkonen, Phys. Scr., 28: 188 (1983).

12. O. Keski-Rahkonen, K. Reinikainen, and E. Mikkola, Phys. Scr., 28: 179 (1983).

13. N. A. Borovoi and Yu. P. Gololobov, Phys. Sol. State, 39, No. 9: 1474 (1997).

14. A. Salnik, Yu. P. Gololobov, and N. A. Borovoy, Ferroelectrics, 484: 62 (2015).

15. M. O. Krause and J. H. Oliver, J. Phys. Chem. Ref. Data, 8, No. 2: 329 (1979).

16. M. O. Krause, J.Phys. Chem. Ref. Data, 8, No. 2: 307 (1979).

17. M. H. Chen and B. Crasemann, Atom. Data Nucl. Data Tabl., 8: 13 (1979). 